Bent-Are Hansen (f. 1984) er lege i spesialisering ved Medisinsk avdeling, Haukeland universitetssykehus.

Ingen oppgitte interessekonflikter.

\author{
Litteratur \\ 1. Aa E, Simensen ASRE. Magnesiummangel og protonpumpehemmere. Tidsskr \\ Nor Legeforen 2016; 136: 1336.
}

\section{Re: Vi skal alle gjøre feil}

Semesterstart er som kjent tiden for de store, høytsvevende visjoner. Denne gangen er det Petter Gjersvik som er ute og svinger pennen (1). Han har selvfølgelig rett når han skriver at «tilbakemeldinger på egne prestasjoner og handlinger er avgjørende for god læring.» Problemet er at han fremstiller det som om vi studenter ikke ser verdien av kritikk, eller for å bruke hans ord, at vi foretrekker «passiv mating av fakta.»

Realiteten er at vi tørster etter flere og bedre tilbakemeldinger på studiet. De er nemlig tilnærmet fraværende. Da vi startet på medisinstudiet ble vi overrasket over hvor udelt positive legene var til våre famlende forsøk på anamnese og undersøkelse. Vi tenkte at det ville endre seg utover i studiet, at vi etterhvert ville bli behandlet som voksne mennesker som tålte ærlige tilbakemeldinger, på godt og vondt. At vi ville bli stilt krav til.

Fem år senere har vi fortsatt til gode - med noen få hederlige unnta - å oppleve dette. Å stille uforberedt til undervisning er ikke noe problem ved medisinstudiet i Oslo. Underviserne er så redde for å tråkke på studentenes tær, at man slipper unna med tilnærmet hva som helst. Det motiverer ikke, og det fremmer ikke faglig utvikling.

Det er tydelig at Gjersvik og fakultetet har fått med seg at vi trenger mer tilbakemeldinger. Problemet er bare at løsningen deres er helt feil. Tendensen til å innføre stadig flere obligatoriske presentasjoner for studentene er kun et behagelig blindspor for underviserne. Når studentene klager over at det kaster bort tiden vår, er ikke det fordi vi er late, det er fordi vi lærer lite av det. Å lese opp fire forberedte setninger om veneriske sykdommer gjør oss ikke til bedre leger.

Karakterer er fakultetets andre svar. Det kan godt hende at vi vil lese mer, men våre kliniske kommunikasjonsferdigheter, vår undersøkelsesteknikk og vår evne til kritisk resonnering rundt komplekse sykdomsbilder, blir ikke bedre. Det er bare tilbakemeldinger i klinisk praksis som kan fylle dette tomrommet. Kanskje skulle både studenter og undervisere hatt opplæring i hvordan man gir og mottar konkret og berettiget tilbakemelding (2).

Kjære fremtidige kolleger. Fortell oss hva vi kan bli bedre på, og si ifra når det vi gjør ikke er godt nok. Vi ønsker å kjenne på skammen og flauheten ved å få påpekt feil. Vi vil kjenne på det så mange ganger, at den dagen vi faktisk gjør en feil som teller, så er vi leger nok til å innrømme det.

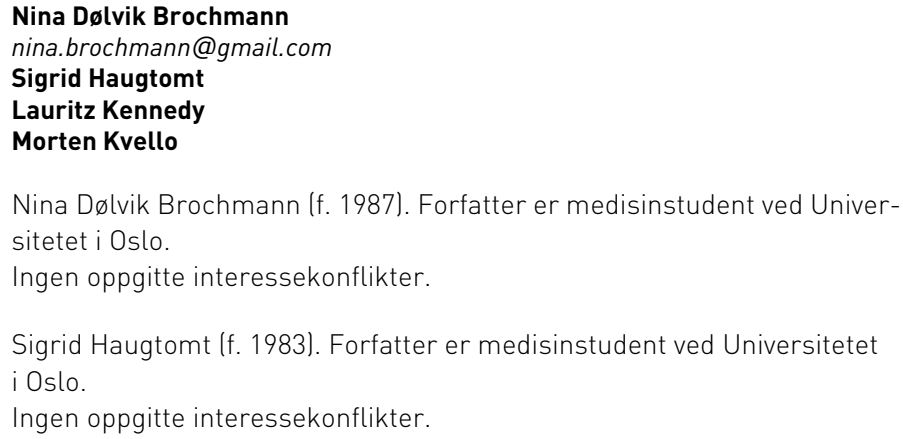

Nina Dølvik Brochmann (f. 1987). Forfatter er medisinstudent ved Universitetet i Oslo.

Ingen oppgitte interessekonflikter.

Sigrid Haugtomt (f. 1983). Forfatter er medisinstudent ved Universitetet i Oslo.

Ingen oppgitte interessekonflikter.

Lauritz Kennedy (f. 1987). Forfatter er medisinstudent ved Universitetet i Oslo.

Ingen oppgitte interessekonflikter.

Morten Kvello (f. 1991). Forfatter er medisinstudent ved Universitetet i Oslo.

Ingen oppgitte interessekonflikter

\section{Litteratur}

1. Gjersvik P. Vi skal alle gjøre feil. Tidsskr Nor Legeforen 2016; 136: 1179

2. van de Ridder JM, Stokking KM, McGaghie WC et al. What is feedback in clinical education? Med Educ 2008; 42: 189-97.

\section{P. Gjersvik svarer:}

Takk til Brochmann og medarbeidere for et tankevekkende innlegg. De har et klart og utvetydig budskap til oss lærere: Vi svikter studentene når vi ikke gir dem tilbakemeldinger i undervisningen. Dette er kritikk vi må ta på alvor. Her har lærere og fakultetsledelse en jobb å gjøre.

Når det gjelder opplegget med studentforberedt undervisning, som vi har praktisert i faget hud- og veneriske sykdommer i Oslo de siste årene, er det mer uklart hva de mener. Deres utsagn om «å lese opp fire forberedte setninger om veneriske sykdommer» er ikke representativt. Vi har faktisk aldri brukt et venerologisk emne til denne undervisningen.

At studenter og lærere har ulikt syn på eksamen og karakterer, er ikke noe nytt. Man kan mislike det, men det er liten tvil om at eksamen og karakterer i stor grad er styrende for studentenes studieatferd. Og eksamen skal ikke bare teste kunnskap, slik Brochmann og medarbeidere synes å mene, men også evnen til kommunikasjon, pasientundersøkelse og klinisk resonnement.

Brochmann og medarbeidere foreslår at studenter og undervisere bør få opplæring i hvordan man gir og mottar tilbakemeldinger. Dette er et godt forslag som studieledelsen ved fakultetene bør vurdere.

\section{Petter Gjersvik}

petter.gjersvik@medisin.uio.no

Petter Gjersvik (f. 1952) er medisinsk redaktør i Tidsskriftet, førsteamanuensis og undervisningsleder i hud-og veneriske sykdommer ved Universitetet i Oslo.

Ingen oppgitte interessekonflikter.

\section{Re: Medikamentetterlevelse og monitorering av antihypertensiv behandling}

Takk for en meget interessant og relevant oversiktsartikkel, der en blant annet omtaler nytten av terapeutisk legemiddelmonitorering som virkemiddel for å fremme legemiddeletterlevelse hos pasienter som behandles med antihypertensiva (1). Behov for kontroll av legemiddeletterlevelse (compliance) er en av flere kliniske situasjoner der terapeutisk legemiddelmonitorering kan være indisert (2).

Samtidig vil jeg benytte anledningen til å minne om at analyserepertoaret ved mange av landets 50 laboratorier endres raskt (3), og at Norsk forening for klinisk farmakologi derfor i mars 2015 lanserte Farmakologiportalen, fagmiljøets egen oversikt over slike analyser (4). Her finner man en felles oppdatert farmakologisk analyseoversikt for norske laboratorier, med både søkefunksjon og listevisning for substanser, laboratorier og fagstoff. Slik kan man til enhver tid finne ut hvilke legemiddel- og rusmiddelanalyser som tilbys, og hvor. 